\title{
Marmoricola aequoreus sp. nov., a novel actinobacterium isolated from marine sediment
}

\author{
Soon Dong Lee
}

Correspondence

Soon Dong Lee

sdlee@cheju.ac.kr
Department of Science Education, Cheju National University, Jeju 690-756, Republic of Korea

A yellow-coloured, marine actinobacterium, designated SST- $45^{\top}$, was isolated from sandy sediment under the surface of a beach and taxonomically characterized by physiological, chemotaxonomic and phylogenetic methods. The cells of the isolate were Gram-positive, aerobic, non-sporulating, non-motile, spherical cells that occurred singly, in pairs, in clusters or as short chains. The isolate grew at $10-37^{\circ} \mathrm{C}$, an initial pH $5.1-12.1$ and in the presence of $5 \%(\mathrm{w} / \mathrm{v}) \mathrm{NaCl}$. The organism possessed LL-2,6-diaminopimelic acid as the diagnostic diamino acid in the cell wall, MK-8 $\left(\mathrm{H}_{4}\right)$ as the major menaquinone, a polar lipid profile including diphosphatidylglycerol, phosphatidylglycerol, phosphatidylinositol and an unknown phospholipid, $\mathrm{C}_{18: 1}$ and $\mathrm{C}_{16: 0}$ as the major fatty acids, and a DNA G $+\mathrm{C}$ content of $72.4 \mathrm{~mol} \%$. A phylogenetic analysis based on $16 \mathrm{~S}$ rRNA gene sequences showed that the organism was related to members of the genera Marmoricola and Nocardioides. The closest neighbours were Marmoricola aurantiacus DSM $12652^{\top}$ (97.0\% sequence similarity) and Nocardioides jensenii KCTC $9134^{\top}(96.7 \%)$. The combination of morphological and chemotaxonomic characters supported the assignment of the isolate to the genus Marmoricola. However, the organism is clearly distinguished phenotypically from the single described species of this genus, Marmoricola aurantiacus. Based on the data obtained, the organism has been assigned as a novel species, for which the name Marmoricola aequoreus sp. nov. is proposed. The type strain is strain SST $-45^{\top}\left(=\mathrm{JCM} 13812^{\top}=\mathrm{NRRL}\right.$ B-24464 $4^{\top}$.
The genus Marmoricola was proposed by Urzì et al. (2000) for a Gram-positive, aerobic, non-motile, non-sporulating, spherical bacterium without a rod-coccus life cycle, and currently contains only the type strain of the type species, Marmoricola aurantiacus DSM $12652^{\mathrm{T}}$, which was isolated from the surface of a marble statue. The genus was chemotaxonomically characterized as having LL-2,6-diaminopimelic acid in the cell wall, $\mathrm{MK}-8\left(\mathrm{H}_{4}\right)$ as the major menaquinone, the characteristic phospholipids phosphatidylinositol, phosphatidylglycerol and diphosphatidylglycerol, and a cellular fatty acid pattern consisting of straightchain saturated and monounsaturated components, with tuberculostearic acid as the only branched-chain fatty acid. This genus, together with the phylogenetically related genera Nocardioides (Prauser, 1976) and Aeromicrobium (Miller et al., 1991), belongs to the family Nocardioidaceae Nesterenko et al. 1985 emend. Rainey et al. 1997 (Nesterenko et al., 1985; Stackebrandt et al., 1997).

The GenBank/EMBL/DDBJ accession number for the 16S rRNA gene sequence of strain SST-45T is AM295338.

A table of comparative fatty acid data is available as supplementary data with the online version of this paper.
Strain SST- $45^{\mathrm{T}}$ studied in this work was isolated from a sandy sediment sample ( $1 \mathrm{~m}$ below the surface) taken from Samyang beach in Jeju, Republic of Korea. The isolation agar (SC-SW) and procedure have been reported previously (Lee, 2006). A colony was subcultured on yeast extract/malt extract agar (Shirling \& Gottlieb, 1966) prepared in a $60: 40$ mixture of natural sea water and distilled water (YE-SW agar). Pure cultures were maintained in $20 \%(\mathrm{v} / \mathrm{v})$ glycerol suspensions containing $20 \%(\mathrm{v} / \mathrm{v})$ distilled water and $60 \%$ $(\mathrm{v} / \mathrm{v})$ natural sea water at -20 and $-80{ }^{\circ} \mathrm{C}$.

Chromosomal DNA was extracted and purified by using the method of Hopwood et al. (1985). The G+C content of DNA was determined by HPLC as described by Mesbah et al. (1989). The DNA G $+\mathrm{C}$ content of strain SST- $45^{\mathrm{T}}$ was $72.4 \mathrm{~mol} \%$. The chromosomal $16 \mathrm{~S}$ rRNA gene was amplified by PCR as described previously (Lee et al., 2000). The resultant PCR product was directly sequenced using an $A B I$ PRISM BigDye Terminator cycle sequencing kit (Applied Biosystems) and an automatic DNA sequencer (Model 3730xl; Applied Biosystems). A partial 16S rRNA gene sequence for strain SST- $45^{\mathrm{T}}$ (1398 nt) was determined in this study. The result of a preliminary BLAST search showed that the organism was related to members of the family Nocardioidaceae. The sequence was aligned with those 
of related organisms retrieved from GenBank by using CLUSTAL_X (Thompson et al., 1997). Phylogenetic analyses and tree construction were carried out using several treemaking algorithms, as described by Lee (2006).

The neighbour-joining tree (Fig. 1) showed that the organism was related to members of the genera Marmoricola and Nocardioides. The closest neighbours were Marmoricola aurantiacus DSM $12652^{\mathrm{T}}$ (97.0\% sequence similarity) and Nocardioides jensenii KCTC $9134^{\mathrm{T}}(96.7 \%)$. All tree-making algorithms used in this study supported the phylogenetic relationships of the isolate with Marmoricola aurantiacus and Nocardioides jensenii. Levels of 16S rRNA gene sequence similarities of strain SST $-45^{\mathrm{T}}$ to other Nocardioides species and representatives of the genus Aeromicrobium were in the ranges of $92.1-95.5 \%$ and $93.2-93.5 \%$, respectively.

Cell morphology and motility were observed using phasecontrast and transmission electron microscopes. Cells were grown on YE-SW agar at $30^{\circ} \mathrm{C}$ for 15,24 and $72 \mathrm{~h}$. Colony pigmentation was observed visually and recorded after incubation for 5 days at $30^{\circ} \mathrm{C}$ on YE-SW agar. Growth was tested on YE-SW agar at temperatures of 4, 10, 20, 30, 37 and $42{ }^{\circ} \mathrm{C}$, and at $\mathrm{pH} 4.1-12.1$. To test the $\mathrm{pH}$ for growth, the $\mathrm{pH}$ of the basal medium was adjusted at intervals of 1.0, after autoclaving, with $6 \mathrm{M} \mathrm{HCl}$ and $10 \mathrm{M} \mathrm{NaOH}$. $\mathrm{NaCl}$ tolerance for growth was studied on yeast extract-malt extract agar, with the addition of $\mathrm{NaCl}$ at final concentrations of $0-9 \%$ $(\mathrm{w} / \mathrm{v})$. The ability to utilize a variety of substrates as sole carbon source was determined using ISP 9 medium (Shirling \& Gottlieb, 1966). Each filter-sterilized carbon source was added in the basal medium at a final concentration of $1 \%$ $(\mathrm{w} / \mathrm{v})$ for carbohydrates and alcohols, and at $0.1 \%(\mathrm{w} / \mathrm{v})$ for organic acids. Strain SST- $45^{\mathrm{T}}$ was grown on YE-SW agar at $30^{\circ} \mathrm{C}$ for 3 days and harvested by scraping the cells from the agar surface with a sterile cotton swab. After washing twice with sterile distilled water, cells were resuspended in distilled water before using them as an inoculum. The production of hydrogen sulfide was detected on Trypticase Soy Broth (TSB; Difco) by using lead acetate strips. Catalase activity was determined with a $3 \%(\mathrm{v} / \mathrm{v}) \mathrm{H}_{2} \mathrm{O}_{2}$ solution. Urease activity was determined using Bacto urea broth (Difco). Oxidase activity and Gram staining were determined as described by MacFaddin (1980). Decomposition of hypoxanthine, DL-tyrosine and xanthine were examined by the method of Gordon et al. (1974). Nitrate reduction, casein hydrolysis and gelatin liquefaction were examined by using the methods of MacFaddin (1980). The ability to hydrolyse starch was determined using starch agar (Difco). The production of acid from carbohydrates and alcohols was determined on Bacto OF basal medium (Difco) supplemented with a filtersterilized carbon source at a final concentration of $1 \%(\mathrm{w} / \mathrm{v})$. Other enzyme activities were tested by using API ZYM strips, according to the instructions of the manufacturer, with cells grown on YE-SW at $30^{\circ} \mathrm{C}$ for 2 days.

Cells of strain SST- $45^{\mathrm{T}}$ were aerobic, Gram-positive, oxidase-negative, catalase-positive, non-motile and coccoid (Fig. 2), irrespective of culture age. After incubation on
YE-SW at $30^{\circ} \mathrm{C}$ for 5 days, the colonies were bright yellow in colour and circular, smooth and convex with an entire margin. Cells of strain SST- $45^{\mathrm{T}}$ showed an ability to utilize a variety of substrates, namely carbohydrates, alcohols and organic acids as sole carbon and energy sources for growth. The optimum temperature and $\mathrm{pH}$ of the isolate were $30^{\circ} \mathrm{C}$ and $\mathrm{pH}$ 7.1, respectively. Detailed results of the physiological characterization are given in Table 1 and in the species description below.

Chemotaxonomic analyses were performed as described by Lee (2006). The isomer of diaminopimelic acid in the cell wall, isoprenoid quinones, polar lipids and mycolic acids were determined according to the methods of Staneck \& Roberts (1974), Kroppenstedt (1985), Minnikin et al. (1977) and Minnikin et al. (1980), respectively. To determine cellular fatty acid composition, strain SST- $45^{\mathrm{T}}$ was grown on TSB supplemented with Bacto agar (Difco) at $30^{\circ} \mathrm{C}$ for 3 days. Cellular fatty acid methyl esters were prepared and analysed using the Sherlock Microbial Identification System (version 6.0 ; MIDI), according to the instructions of the manufacturer. The determined chemotaxonomic markers (given in the species description) were consistent with those of Marmoricola aurantiaca. The cellular fatty acids of strain SST- $45^{\mathrm{T}}$ were represented by straight-chain saturated and unsaturated acids and consisted predominantly of $\mathrm{C}_{18: 1}(40.1 \%)$ and $\mathrm{C}_{16: 0}$ (35.0\%). Minor components were $\mathrm{C}_{14: 0}(1.4 \%), \mathrm{C}_{17: 0}$ (2.9\%), $\mathrm{C}_{18: 0}(7.6 \%), \mathrm{C}_{16: 1}(6.6 \%)$ and $\mathrm{C}_{17: 1}(2.0 \%)$. The fatty acid profile of strain SST- $45^{\mathrm{T}}$ differed from that of Marmoricola aurantiaca in the absence/presence of $10-\mathrm{Me}$ $\mathrm{C}_{18: 0}$ and some other minor acids (see supplementary Table S1 with the online version of this paper). This difference, however, may be due to different growth and analysis conditions as demonstrated for some actinobacterial species (Park et al., 1999; Sohn et al., 2003; Trujillo et al., 2006).

The isolate also differed from Marmoricola aurantiaca in the yellow-pigmented colonies, growth at $37^{\circ} \mathrm{C}$ and in the presence of $5 \%(\mathrm{w} / \mathrm{v}) \mathrm{NaCl}$, the ability to reduce nitrate and to produce acid from maltose, and some degradation activities (Table 1). On the other hand, the other phylogenetic neighbour, Nocardioides jensenii, as well as other members of that genus, showed a striking dissimilarity to the isolate by the presence of iso- and anteiso-branched fatty acids, and in their rod-shaped cells or fragmenting mycelium (Collins et al., 1989; Miller et al., 1991; Prauser, 1976; Schumann et al., 1997; Suzuki \& Komagata, 1983; Tamura \& Yokota, 1994).

On the basis of the phenotypic and phylogenetic data, it was shown that the isolate merits classification as a novel species of the genus Marmoricola for which the name Marmoricola aequoreus sp. nov. is proposed. The type strain is SST- $45^{\mathrm{T}}$ $\left(=\right.$ JCM $13812^{\mathrm{T}}=$ NRRL B-24464 $\left.{ }^{\mathrm{T}}\right)$.

\section{Description of Marmoricola aequoreus sp. nov.}

Marmoricola aequoreus (ae.qu.o.re' us. L. masc. adj. aequoreus belonging to the sea, referring to the isolation of the type strain from the sea). 


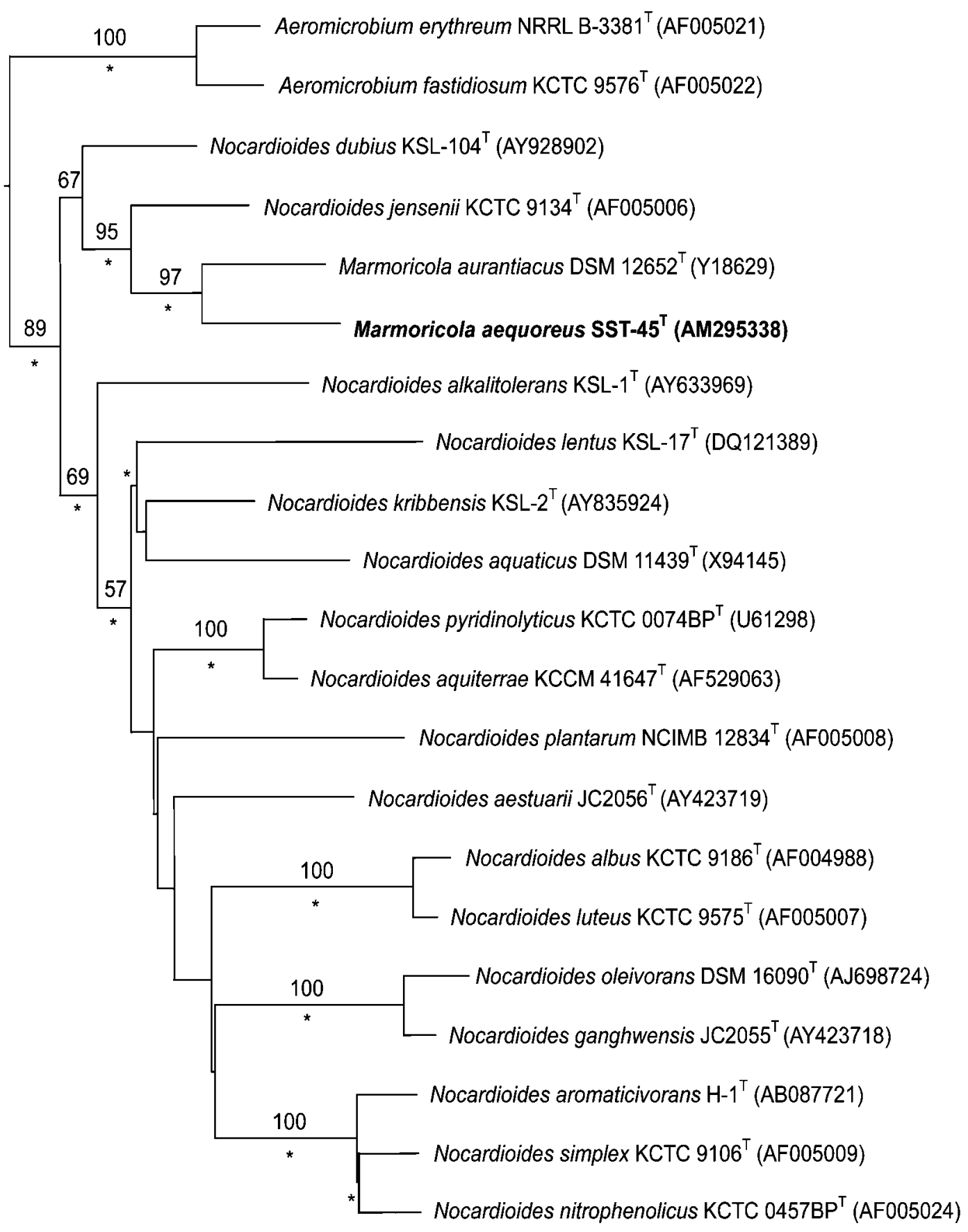

$1 \%$

Fig. 1. A phylogenetic tree showing the relationship of strain SST-45 ${ }^{\top}$ with members of related genera in the family Nocardioidaceae. The tree was constructed using the neighbour-joining method (Saitou \& Nei, 1987) and the method of Jukes \& Cantor (1969). Streptomyces griseus was used as an outgroup. Asterisks indicate branches of the tree that were recovered using both maximum-likelihood (Felsenstein, 1981) and maximum-parsimony (Fitch, 1971) methods. Bootstrap values of 1000 analyses are shown at the top of the branching points for neighbour-joining analysis (only values greater than $50 \%$ are indicated). Bar, 1 substitution per 100 nt positions. 
Table 1. Phenotypic characteristics that differentiate strain $S S T-45^{\top}$ from the type strain of Marmoricola aurantiacus

Data for strain DSM $12652^{\mathrm{T}}$ are taken from Urzi et al. (2000). Results were recorded as: +, positive; - , negative.

\begin{tabular}{|c|c|c|}
\hline Characteristic & SST $-45^{\mathrm{T}}$ & DSM $12652^{\mathrm{T}}$ \\
\hline Colour of colony & Yellow & Orange \\
\hline Cell morphology & Coccus, $0.5-0.7 \mu \mathrm{m}$ & Coccus, $0.5-0.6 \mu \mathrm{m}$ \\
\hline Growth at $37^{\circ} \mathrm{C}$ & + & - \\
\hline Growth on $5 \% \mathrm{NaCl}$ & + & - \\
\hline Nitrate reduction & + & - \\
\hline \multicolumn{3}{|l|}{ Hydrolysis of: } \\
\hline Casein & + & - \\
\hline Gelatin & + & - \\
\hline Hypoxanthine & - & + \\
\hline Acid production from maltose & + & - \\
\hline DNA G + C content $(\mathrm{mol} \%)$ & 72.4 & 72.0 \\
\hline Origin of isolation & Beach sediment & Marble \\
\hline
\end{tabular}

Cells are aerobic, Gram-positive, non-spore-forming and non-motile cocci $(0.5-0.7 \mu \mathrm{m}$ in diameter) that occur singly, in pairs, as clusters or as short chains. Colonies are circular, smooth, convex and bright yellow in colour. Chemoheterotrophic. Growth is good at $10-37^{\circ} \mathrm{C}$, but poor at $4{ }^{\circ} \mathrm{C}$, and does not occur at $42^{\circ} \mathrm{C}$. Growth occurs at an initial $\mathrm{pH}$ of 5.1-12.1, with an optimum at $\mathrm{pH}$ 7.1. Good growth is observed at $0-5 \%(\mathrm{w} / \mathrm{v}) \mathrm{NaCl}$, but poor at $6-7 \%$ $(\mathrm{w} / \mathrm{v}) \mathrm{NaCl}$. Nitrate is reduced to nitrite. Gelatin is liquefied. Aesculin and casein are hydrolysed. $\mathrm{H}_{2} \mathrm{~S}$ production is observed. Hypoxanthine, DL-tyrosine or xanthine are not degraded. Urease activity is not detected. Acid is produced from dextran, maltose and salicin. No acid is produced from L-arabinose, D-arabinose, D-cellobiose, D-fructose, D-galactose, D-glucose, inulin, D-lactose, D-mannose, D-melezitose, methyl- $\alpha$-D-glucoside, methyl- $\alpha$-D-mannoside, D-raffinose, L-rhamnose, L-ribose, L-sorbose, sucrose, D-trehalose, Dxylose, adonitol, 2,3-butanediol, D-dulcitol, meso-erythritol, glycerol, meso-inositol, D-mannitol, 1,2-propanediol, Dsorbitol or D-xylitol. In the API ZYM system, alkaline phosphatase, leucine arylamidase, valine arylamidase and $\alpha$-glucosidase are positive. The following tests are weakly positive: esterase lipase (C8), crystine arylamidase, $\beta$-galactosidase and $\beta$-glucosidase. Esterase (C4), lipase (C14), trypsin, $\alpha$-chymotrypsin, acid phosphatase, naphthol-ASBI-phosphohydrolase, $\alpha$-galactosidase, $\beta$-glucuronidase, $N$ acetyl- $\beta$-glucosaminidase, $\alpha$-mannosidase and $\alpha$-fucosidase are negative. The following compounds are utilized as sole carbon and energy sources: D-cellobiose, dextran, D-fructose, D-galactose, D-glucose, inulin, D-lactose, maltose, D-mannose, D-melezitose, methyl- $\alpha$-D-glucoside, L-ribose, sucrose, D-trehalose, D-xylose, glycerol, D-mannitol, 1,2propanediol and D-sorbitol. Assimilation of acetate, citrate, malate and succinate is detected. The following carbon sources are not utilized: L-arabinose, D-arabinose, methyl- $\alpha$ D-mannoside, D-raffinose, L-rhamnose, salicin, L-sorbose,
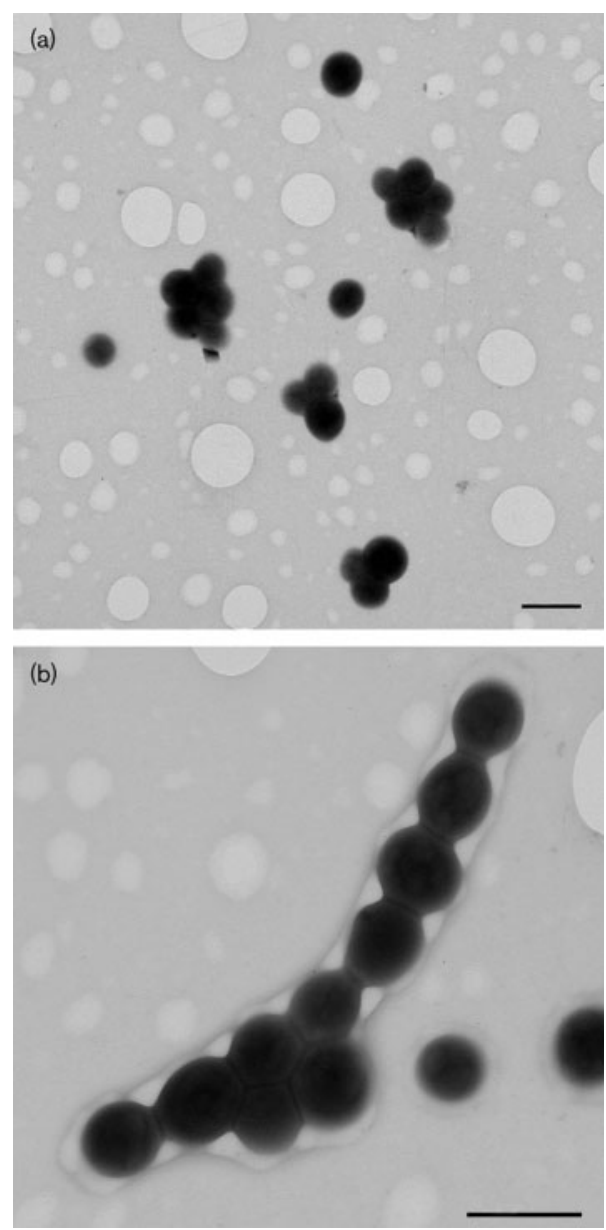

Fig. 2. Electron microscopy of strain $S S T-45^{\top}$ grown on YESW agar for $72 \mathrm{~h}$ at $30^{\circ} \mathrm{C}$. (a) Cocci as aggregates; (b) cocci in a short chain. Bars, $1 \mu \mathrm{m}$. 
adonitol, 2,3-butanediol, D-dulcitol, meso-erythritol, mesoinositol and D-xylitol. Tests for benzoate, formate and tartrate assimilation are negative. LL-2,6-Diaminopimelic acid is the diagnostic diamino acid in the cell wall. The predominant menaquinone is MK- $8\left(\mathrm{H}_{4}\right)$. The polar lipids contain phosphatidylinositol, diphosphatidylglycerol, phosphatidylglycerol and an unknown phospholipid. The predominant cellular fatty acids are $\mathrm{C}_{18: 1}$ and $\mathrm{C}_{16: 0}$. The $\mathrm{G}+\mathrm{C}$ content of the DNA is $72.4 \mathrm{~mol} \%$.

The type strain is strain SST $-45^{\mathrm{T}}\left(=\mathrm{JCM} 13812^{\mathrm{T}}=\right.$ NRRL B$24464^{\mathrm{T}}$ ), isolated from sandy sediment of Samyang beach in Jeju Island, Republic of Korea.

\section{Acknowledgements}

This work was supported by the 21C Frontier Microbial Genomics and Application Center Program, Ministry of Science and Technology, Republic of Korea.

\section{References}

Collins, M. D., Dorsch, M. \& Stackebrandt, E. (1989). Transfer of Pimelobacter tumescens to Terrabacter gen. nov. as Terrabacter tumescens comb. nov. and of Pimelobacter jensenii to Nocardioides as Nocardioides jensenii comb. nov. Int J Syst Bacteriol 39, 1-6.

Felsenstein, J. (1981). Evolutionary trees from DNA sequences: a maximum likelihood approach. J Mol Evol 17, 368-376.

Fitch, W. M. (1971). Towards defining the course of evolution: minimum change for a specific tree topology. Syst Zool 20, 406-416.

Gordon, R. E., Barnett, D. A., Handerhan, J. E. \& Pang, C. H.-N. (1974). Nocardia coeliaca, Nocardia autotrophica, and the nocardin strain. Int J Syst Bacteriol 24, 54-63.

Hopwood, D. A., Bibb, M. J., Chater, K. F., Kieser, T., Bruton, C. J., Kieser, H. M., Lydiate, D. J., Smith, C. P., Ward, J. M. \& Schrempf, H. (1985). Genetic Manipulation of Streptomyces: a Laboratory Manual. Norwich: John Innes Foundation.

Jukes, T. H. \& Cantor, C. R. (1969). Evolution of protein molecules. In Mammalian Protein Metabolism, pp. 21-132. Edited by $\mathrm{H} . \mathrm{N}$. Munro. New York: Academic Press.

Kroppenstedt, R. M. (1985). Fatty acid and menaquinone analysis of actinomycetes and related organisms. In Chemical Methods in Bacterial Systematics, pp. 173-199. Edited by M. Goodfellow \& D. E. Minnikin. London: Academic Press.

Lee, S. D. (2006). Kineococcus marinus sp. nov., isolated from marine sediment of the coast of Jeju, Korea. Int J Syst Evol Microbiol 56, 1279-1283.

Lee, S. D., Kang, S.-O. \& Hah, Y. C. (2000). Hongia gen. nov., a new genus of the order Actinomycetales. Int J Syst Evol Microbiol 50, 191-199.

MacFaddin, J. F. (1980). Biochemical Tests for Identification of Medical Bacteria, 2nd edn. Baltimore: Williams \& Wilkins.

Mesbah, M., Premachandran, U. \& Whitman, W. B. (1989). Precise measurement of the $\mathrm{G}+\mathrm{C}$ content of deoxyribonucleic acid by highperformance liquid chromatography. Int J Syst Bacteriol 39, 159-167.
Miller, E. S., Woese, C. R. \& Brenner, S. (1991). Description of the erythromycin-producing bacterium Arthrobacter sp. strain NRRL B-3381 as Aeromicrobium erythreum gen. nov., sp. nov. Int J Syst Bacteriol 41, 363-368.

Minnikin, D. E., Patel, P. V., Alshamaony, L. \& Goodfellow, M. (1977). Polar lipid composition in the classification of Nocardia and related bacteria. Int J Syst Bacteriol 27, 104-117.

Minnikin, D. E., Hutchinson, I. G., Caldicott, A. B. \& Goodfellow, M. (1980). Thin layer chromatography of methanolysates of mycolic acid-containing bacteria. J Chromatogr 188, 221-233.

Nesterenko, O., Kvasnikov, E. I. \& Nogina, T. M. (1985) Nocardioidaceae fam. nov., a new family of the order Actinomycetales Buchanan 1917. Mikrobiol Zh 47, 3-12.

Park, Y. H., Yoon, J. H., Shin, Y. K., Suzuki, K., Kudo, T., Seino, A., Kim, H. J., Lee, J. S. \& Lee, S. T. (1999). Classification of 'Nocardioides fulvus' IFO 14399 and Nocardioides sp. ATCC 39419 in Kribbella gen. nov., as Kribbella flavida sp. nov. and Kribbella sandramycini sp. nov. Int J Syst Evol Microbiol 49, 743-752.

Prauser, H. (1976). Nocardioides, a new genus of the order Actinomycetales. Int J Syst Bacteriol 26, 58-65.

Saitou, N. \& Nei, M. (1987). The neighbor-joining method: a new method for reconstructing phylogenetic trees. Mol Biol Evol 4, 406-425.

Schumann, P., Prauser, H., Rainey, F. A., Stackebrandt, E. \& Hirsch, P. (1997). Friedmanniella antarctica gen. nov., sp. nov., an LL-diaminopimelic acid-containing actinomycete from Antarctic sandstone. Int J Syst Bacteriol 47, 278-283.

Shirling, E. B. \& Gottlieb, D. (1966). Methods for characterization of Streptomyces species. Int J Syst Bacteriol 16, 313-340.

Sohn, K., Hong, S. G., Bae, K. S. \& Chun, J. (2003). Transfer of Hongia koreensis Lee et al. 2000 to the genus Kribbella Park et al. 1999 as Kribbella koreensis comb. nov. Int J Syst Evol Microbiol 53, 1005-1007.

Stackebrandt, E., Rainey, F. A. \& Ward-Rainey, N. L. (1997). Proposal for a new hierarchic classification system, Actinobacteria classis nov. Int J Syst Bacteriol 47, 479-491.

Staneck, J. L. \& Roberts, G. D. (1974). Simplified approach to identification of aerobic actinomycetes by thin-layer chromatography. Appl Microbiol 28, 226-231.

Suzuki, K. \& Komagata, K. (1983). Pimelobacter gen. nov., a new genus of coryneform bacteria with LL-diaminopimelic acid in the cell wall. J Gen Appl Microbiol 29, 59-71.

Tamura, T. \& Yokota, A. (1994). Transfer of Nocardioides fastidiosa Collins and Stackebrandt 1989 to the genus Aeromicrobium as Aeromicrobium fastidiosum comb. nov. Int J Syst Bacteriol 44, 608-611.

Thompson, J. D., Gibson, T. J., Plewniak, F., Jeanmougin, F. \& Higgins, D. G. (1997). The ClustalX windows interface: flexible strategies for multiple sequence alignment aided by quality analysis tools. Nucleic Acids Res 24, 4876-4882.

Trujillo, M. E., Kroppenstedt, R. M., Schumann, P. \& MartínezMolina, E. (2006). Kribbella lupini sp. nov., isolated from the roots of Lupinus angustifolius. Int J Syst Evol Microbiol 56, 407-411.

Urzì, C., Salamone, P., Schumann, P. \& Stackebrandt, E. (2000). Marmoricola aurantiacus gen. nov., sp. nov., a coccoid member of the family Nocardioidaceae isolated from a marble statue. Int J Syst Evol Microbiol 50, 529-536. 